\title{
Normalization Strategy as The Concept of Power in The Dutch-Indies Literature: Michel Foucault Critical Discourse Analysis Perspective
}

\author{
I Sukowati \\ UNISDA Lamongan \\ Lamongan, Indonesia
}

\begin{abstract}
The background of this research problem is an attempt to prove that literature as collective consciousness product, in this case the Indies Literature, is not an isolated production form, but always influenced by certain power, social and economic system, so it is a discourse that can be used as a tool to organize practical power. Using Critical Discourse Analysis Michel Foucault as a theoretical approach, as well as the method of hermeneutic phenomenology of Paul Ricoeur and interdisciplinary as well as qualitative data analysis techniques developed by Denzin regarding the understanding of savoir (conjunctive knowledge) enriched with conaissance (formal knowledge related to the savoir of this research seeks to see the totality of the discourse relation and the hidden manifest, in order to find the relation of the dominance of the power of knowledge in the literary work, in particular the strategy of normalization in the system of power of knowledge, and the results of the study conclude that a power is not only substantial and inherent and dispersed as Foucault's opinion, the power of knowledge is the duplication of the power cells. Therefore, the power of a power of knowledge can be analogous to $\mathrm{E}_{\mathrm{k}}=\mathrm{M}_{\mathrm{k}} \mathrm{C}^{2}$ the power of power is the result of duplication between the power webs involved and the form $\left(E_{k}=M_{k} C^{2}---E_{k}=\right.$ energy of power, $M_{k}=$ the power net involved, $C^{2}=$ cel-cel power formed). And as far as the understanding of researchers has never been conveyed by Foucault in his discussion of the power of knowledge.
\end{abstract}

Keywords: Dutch-indies literature, analysis perspective

\section{INTRODUCTION}

The form of operational power through the power of knowledge discourse in literary works is very possible, because it cannot be denied that literary works can also build and play a relational role in the power system, as well as the dynamics of power, both political, social and cultural [5]. Therefore, the power strategy discourse in a literary work is very realistic if it can be used practically to control power, which in Foucault terms is known as the strategy of normalization through power. That is why the production of texts by the author is a cultural production connected with power and society [6]. And AWK's focus on efforts to dismantle the power of dominance relation is the consideration of Critical Discourse choosing as a research approach.

\section{METHOD}

\subsection{Type of Research}

This research included the type of descriptive-qualitative research. Descriptive research focuses on specific aspects specifically $[8,9]$. This study aimed to describe in depth about the strategy of normalization in the Dutch Indies Literature, Critical Discourse Analysis Perfective Michel Foucault.

\subsection{Research Approach}

This research used hermeneutic and interdisciplinary phenomenology approach. The hermeneutic phenomenology approach was chosen because the object of this study will interpret the phenomenon of power that appeared in literary works. The phenomenology of hermeneutic Ricoeur according to van Manen (Creswell, 2014: 110).

The source of this research data is in the form of a text of the Dutch East Indies literature in which there are traces of Dutch East Indies artifacts in Indonesia, in this case thirteen novels of Dutch Hindi literature follows: (1) Novel Babad Tanah Jawi (W.L.Ollthof, 1941); (2) Novel Max Havelaar(Multatuli, 1860); (3) Borneo van Zuid naar Noord- (M.T. H. Parelaer, 1870); (4) Goena-goena: oorspronkelijke (Paul Adriaan Daum, 1889): (5) Hikayat Tanah Hindia (G.J.F. Biegman, 1894); (6) Tjerita Nyai Dasima (G.Francis, 1895); (7) Rubber (M.H. Szkely-Lilofs, 1931); (8) Koeli (M.H. SzkelyLilofs, 1932), (9) De Moord op Kapitein Francoise Tack, 8 February 1686 (H.J.de Graaf, 1935); (10) Oeroeg (Hella s.Haasse-1948); (11) Het Laatste Huis van de Wereld (beb Vuyk-1972); (12) Veegeelde Portretten (Rob Niewenhuys1977); (13) Indie Vaarwel: de Beloftie van de Eierboer (Schomper Pans, 1993).

\subsection{Data Collection Techniques}

Data collection techniques is the researchers on the established approaches of Paul Ricoeur hermeneutic and interdisciplinary phenomenology, and qualitative descriptive 
analysis method, that is a hermeneutic circular surgery technique for novel texts involving the many elements that emerge from the reader [4].

\subsection{Data Analysis Technique}

Data analysis is done in accordance with the steps of AWK Michael Foucault, by following the stages: First, data collection, secondly, two descriptions (reading text), thirdhly, interpretations (interpretation of discursive practice of power), fourth, explanations (verification practice of regulation strategy of power of discourse), by referring to the qualitative data analysis whic is developed by Denzin [10], that is an effort to understand Savoir (implicit knowledge) and Conaissance (formal knowledge related with savoir) and involve four stages : (1) Data collection, (2) data reduction, (3) data presentation / description of data, and (4) drawing conclusions.

\section{RESULTS AND DISCUSSION}

The ability to control objects through the internalization of the concept of power in the form of dissemination of knowledge in the power of discourse strategy, is a form of normalization technology found in literary texts Indies. Power discourse strategy selected as the technology of normalization is concepts that try to put a dichotomy or imbalance which refers to the discriminatory behavior as a discourse of control. So that power no longer needs to be conducted in a manner oppressive or limiting, but simply through internalization certain values, so that everyone can take part to help the perpetuation of power. This concept is referred to as normalization technology, , that is able to function as a normalization strategy as found in the following data.

"At that time the Nata ordered weeks to look for beautiful women will be used as concubines. There are people who show that there is a puppeteer set gedog at the mercy of the Mataram kingdom named Ki Wayan had a daughter so beautiful, but has a husband named Ki palace. The King then ordered to immediately pick it up. But the girl was already contains two months. After seeing it the nata so happy and in tempatkannya in the palace.

Kanjeng Sultan until forgotten by the queen for so love the new concubine earlier. Instead appointed queen Wetan. Many people call the Queen of Malang. Not long baby was born late husband, a man with a child of the King's affection. Then commanded Ki Dalem late husband was killed ... The event was marked by sengkalan 1578" (Ollthof, 1941: 183-184).

Discourse Strategies power that can be captured from data (1) and which functioned as a normalization of the technology is that, Raja who incidentally a leader who has the obligation to protect people actually being cruel even have the heart to kill. A Dutch government's efforts to produce new realities about stereotypes ruler of Java (Indonesia) through literature as authoritarian, cunning, petty, greedy, and hedonists. The whole stereotypes negatives above is a form of technology normalization that distort the value system of the concept of leadership Java, deliberately in a discourse on society and will become a common reference that actually means King of Java (Kanjeng Sultan) is humans who are morally has the typology of characters unfit as a leader.

Associated with Foucault's genealogy of power technology as a core principle in childbirth truth, a truth is not necessarily formed without going through the process. There is a process that is patterned in such a way so as to be an imminent truth. An intense truth needs to be constructed in order to become eligible and considered as true (that many kings of Java are unfit to be king because of his behavior no longer fit the traditional political system Java), a form of normalization strategy normalization institutions and values.

The discussions that arose in the data some data showing the forms of knowledge play power practice in literary copyright. Minor discourse is deliberately constructed in the minds of readers through Literature Indies. The colonial government deliberately neglecting in certain themes, as a tool to build a mainstream typology minor of the Kings in Java, which is expected to produce a new truth about the power of kings of Java (manifestation of the power of knowledge) that the end goal of course is to be the objective of power tools. The data shows that literary discourse can function as power technology in the form of normalization strategy, in this case the normalization of the body, normalizing institutions, and normalization of values.

Typology normalization strategy in another form is also used to perform power operation is also found in the following data.

"King together the nobles set up unions and Syahbandar who run ecommerce unionism. No one should make buying and selling except with the permission of the king and the knowledge of the harbormaster. When a ship from a foreign country until in Banten, the skipper must provide all the bill of lading to the king. At first the king of the purchase, after which other people can trade with the captain. So, the king has the monopoly of all kinds of merchandise. While the items out of the Bantam price determined by the harbormaster and royalty trusts. All the goods are not bought or sold by the king charged. The money was shared other charges, for example ruba-ruba (expense ships docked), partly to kings, partly for syahbandar (GJF Biegman, 1894: 47-48). 
Normalization of technology that can be found in the data (2) is "development discourse" which is thought mastery efforts directed at normalizing the body. The goal is the same, i.e. through empirical facts written in literature, the Dutch government has created an effective tool for controlling power through discourse (information). This is in accordance with the concept of power and power Foucault that information cannot be owned by an individual or a group. Power will always flow along with the flow of information. Power can be obtained without having to go through a war. Power can be obtained through the mastery of thought and the management of the public mind; it is what Foucault with the concept of power. Power of knowledge which will become the technology of normalization (folk thought control) or sovereign of knowledge that can be captured in the data (2) squote is.

The first normalization technology in the form of indoctrination that, King Banten (Prince Queen) has a wealth exceeds the average wealth of the nobility another. This discourse is deliberately constructed so that creating jealousy among Banten noble, their social jealousy amongst the nobility would be very beneficial Dutch government. Because then expected to be fired divide the unity of the nobility (royal family of Banten). The advantage is that the Dutch government has been carrying out the political divide et ampere without having to use a weapon. That is meant by Foucault with normalization technology, meaning that normal and real strategy through the mastery of thought right (draft power) is an adequate tool to gain power (sovereign of power) will make the power control device.

Secondly, normalization technology institutions in the form of Power of knowledge that King Banten (Prince Queen) did monopoly in the trade system, be it a monopoly in terms of acquisition of goods, nor a monopoly in terms of the distribution and pricing. Such discourse, and if successfully received as a discourse on power strategy, of course, would be a very effective tool for the Dutch authorities to break the trade partnership between the nobility and the people (nativeChinese-portages) with King Banten. And ultimately will benefit the Dutch government, because they (the nobility and the people) would divert the Dutch government partnership.

Technology normalization of the following (third) which is discoursed based on the data (2) implicitly that the establishment of the regulatory system through an organization called the harbormaster by King Banten (Prince Queen) to regulate the flow of trade at the port of Banten when it simply tricks the king to further enrich themselves and syah bandar (when it is selected from the family of the king). And the power of knowledge that is built up is "ruba-ruba money (expense ships docked) actually means are separately enriching harbormaster and add to the coffers of wealth the king of Banten (Prince Queen).”

As known Syah Bandar who formed the king of offerings as the regulatory system in the dock anchoring Dutch Bantam considered very difficult for them, because it is considered a form of Dutch total monopoly in the trading system in Banten by the authorities. Make the Dutch government did not have space in trade arrangements, and will only obtain low profits. So the Dutch government feels it is necessary to reduce or even destroy the regulative role harbormaster through discourse (discourse in the text). Forms of power of knowledge as a strategy of normalization in literary texts Indies.

Finally, all data presented above show that each power system has several strategies power (power discourse or discourse) that was circulated as an institutionalized truth (received and circulated as true). In this case the normalization strategies that include: (a) Normalized language: the language used as a means of identification characters (labeling/ stereotypes), including the language according to social class. (b) Normalization Body: gymnastics / sport, dress, mannerisms, gestures. (c) Normalization Value: character / character, work ethic, and (d) Normalization institution: the institutional system.

\section{CONCLUSION}

Based on the data analysis of literary texts the Dutch East Indies, it can be concluded that. First, the power of knowledge cannot be assessed from a political or sociological approach to the study of macro. Second, the power of knowledge is always productive and works in the network structure. Third, the more the structure of the network involved in a knowledge power of the net power produced will be more rigid and complicated. And theoretically a structure built of tissues rigid and complex, the structure that will be more powerful and difficult to destroy, because each net power will produce cells with new power, which has the role of game the can no longer be tracked again perfectly from the parent cell.

Similarly, the strength of the duplication of cells produced by the power of knowledge, the study states that a power is not only substantial and inherent and spread as it is opinion of Foucault, but the power of knowledge is the duplication of cells power the discount energy like an atomic explosion with the power of knowledge that can be analogized as $\mathrm{E}_{\mathrm{k}}=\mathrm{M}_{\mathrm{k}} \mathrm{C}^{2}$ power energy is duplicated between the net power involved and the cells that form the power $\left(E_{k}=M_{k} C^{2}---E_{k}=\right.$ energy power, $M_{k}$ $=$ net power are involved, $C^{2}=$ cel-cel power formed $)$. Thus the findings of this study, and as far as understanding the researcher has never delivered discussed in research on the power of knowledge (power of knowledge.

\section{REFERENCES}

[1] J W Creswell, Penelitian Kualitatif \& Desain Riset 3/E-: Memilih di Antara Lima Pendekatan, 2014 
[2] E Locher-Scholten, Women in the Colonial State, Essay on Gender and The Modernity in Netherland Indie 1900-1942, Amsterdam: Amsterdam University Press, 2000

[3] Mawardi, "Sastra Hindia dan Identitas Pribumi", in BASIS No. 03-04, Tahun ke-60, Bandung., 2011

[4] B M Milles and A. Michhel Huberman, Analisis Data Kulaitatif: Buku Sumber ttentang Metode-Metode Baru, Transl. Tjejep Rohendi, from Qualitativ Data Analysis, Jakarta: UI, 2007

[5] T Lemke, "Theory Culture \& Society 0 (0), in New Materialisms: Foucault and the "Government of Things, pp 1-23, 2014, Reprints and Permisions: DOI; $10.177 / 0263276413519340$.

[6] C Venn, "Cultural Theory and its Future; Introduction", in Theory, Culture and Society, Vol. 24 No. 3, pp 79-94, 2007

[7] $\mathrm{R}$ West-Pavlov, Space in theory: Kristeva, Foucault, Deleuze, Amsterdam: Rodopi, 2009

[8] C Juliet and S Anselm, Basics of Qualitative Research, Techniques and Procedures for Developing Grounded Theory, Fourth Edition, Thousand Oaks, California: SAGE Publications, Inc., 2015
[9] M Joseph, "Understanding and Validity in Qualitative Research", in Harvard Educational Review, Vol. 62 No. 3, pp 279-301, 1992

[10] N K Denzin, L S Yvonna, The SAGE Handbook of Quality Research, Thousand Oaks, California: SAGE Publications, Inc., 2011

[11] H Barbara, "Babads on stage: Javanese history and contemporary popular theatre, in Indonesia Circle. Scholl of Oriental \& African Studies, Vol. 9 Issue 26, 1981

[12] Inajati, "Kota gede: an archaeological perspective of a capital city in java in the $17^{\text {th }}$ century", in HUMANORIA, Vol. 17 No. 2, pp 125-134, 2005

[13] E Astrid and R Ann, Meditation, Remediation, and the Dynamics of Cultural Memory, Berlin: Walter de Gruyter GmbH \& Co., 2009

[14] A Julia, "Principals and agents, colonialists and company men: the decay of colonial control in Dutch East Indies", in American Sociological Review, Vol. 61 No. 1, pp 12-28, 1996

[15] S L Ann, Race and the Education of Desire: Foucault's History of Sexuality and the Colonial Order of Things", Durham and London: Duke University Press, 1995. 